Historic, archived document

Do not assume content reflects current scientific knowledge, policies, or practices. 


\section{STOIKS $\mathbb{E} \mathbb{R} \mathbb{R} \mathbb{I} \mathbb{M} \mathbb{N} \mathbb{O}$}

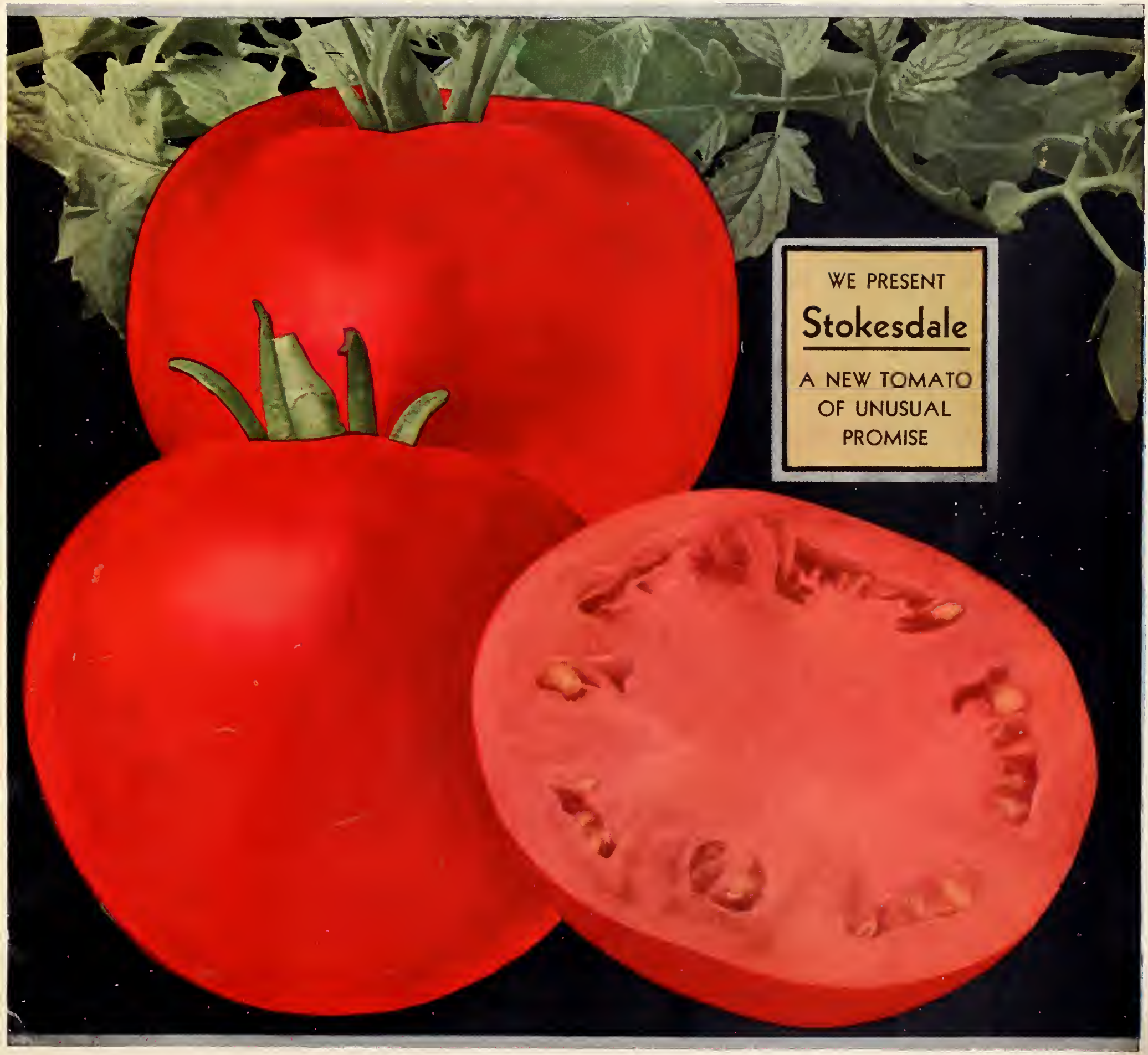




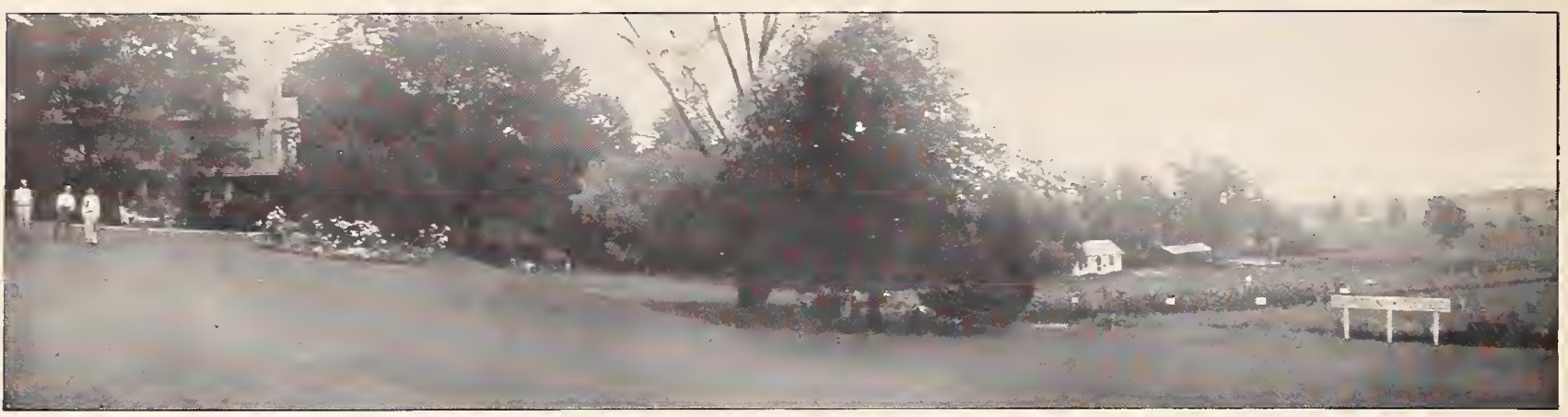

Our Stokesdale Proving Grounds has been the scene of our most important breeding work on Tomatoes for the past four years

\section{STOKESDALE PROVING GROUNDS}

OWN near the mouth of the Thames is a point called The Start. That light marks the commencement of the great voyages. Stokesdale might as aptly be named The Start, for here, too, great journeys commence. This outdoor laboratory of ours covers less than 10 acres, but it is the starting-point of important production for the Tomato industry. Choices made at Stokesdale are multiplied thousands of times within a three-year period.

Each of our breeding-plots is the product of minutely studied singles. These comparatively small stock-seed areas are multiplied for seed-production to about 500 acres the following summer. (This acreage is all under state inspection for certification.) These 500 acres are increased to 50,000 acres in commercial production the summer after that. Thus the multiplication table works at high speed in Tomato propagation.

If Stokesdale stands for anything, it must stand as the symbol of thoroughness of detail, accuracy of measurement, and experience in judgment. Customers are cordially invited to visit us whenever possible. August is the best month. We are 20 minutes distant from Philadelphia by automobile, taking Route 38 from the Camden Airport. It requires two hours to motor from New York, taking Route 25 to Cinnaminson, thence 4 miles to Moorestown. We were honored by visits this past year from persons coming from as far away as Arizona, Texas, Cuba, and Florida. The hand of hospitality is held out to you.

\section{FRANCIS C. STOKES \& COMPANY, Inc. Breeders and Growers of Tomatoes}
STOKESDALE PROVING GROUNDS, MOORESTOWN, NEW JERSEY Sanford, Florida Corpus Christi, Texas Weslaco, Texas St. Catharines, Ontario

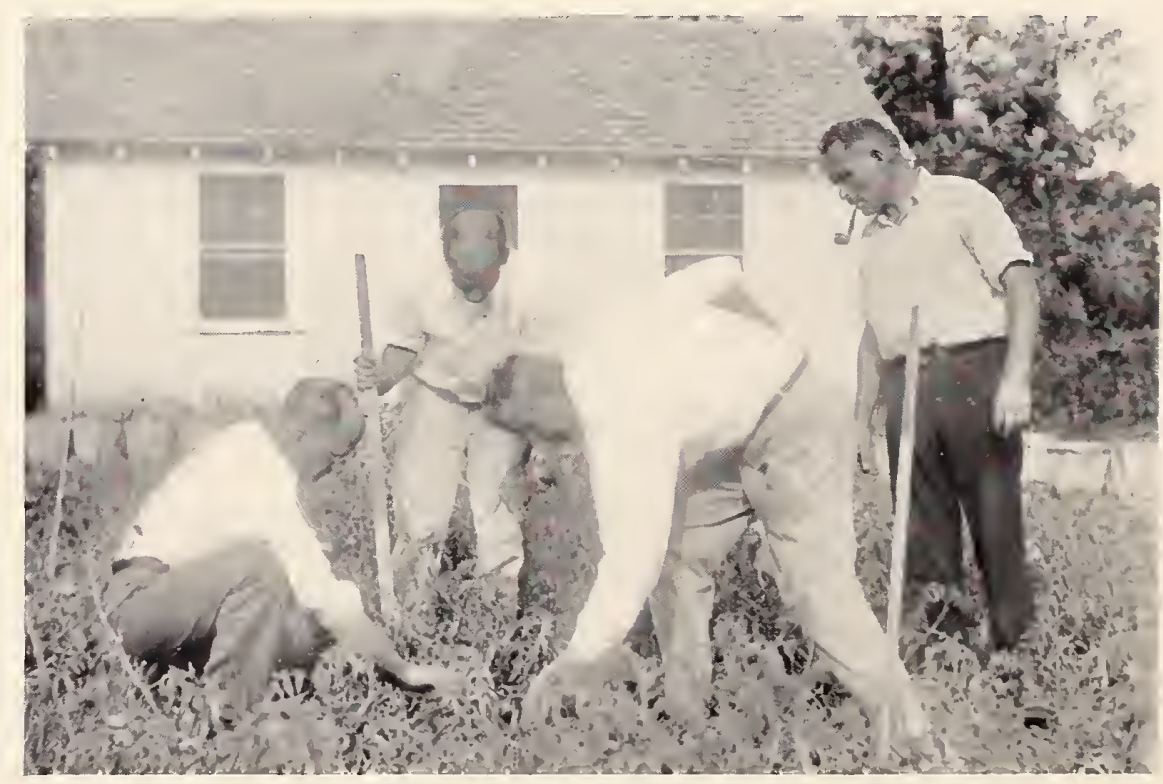

A mistake in judgment here will affect production on 50,000 acres three years hence 


\section{TO

It has been a growing conviction with us that in order to do a job supremely well, one must not only completely master it but immensely enjoy it. Most of us are fitted by training or aptitudes to accomplish certain kinds of work better than other kinds. Will Rogers once said, "If ten men went on a hunting trip, you would soon learn which was the best cook and which was the best hunter to bring in the meat. You would find that each excelled in something useful to all."

For the last ten of our fifty-four years as seedsmen, our principal interest has been in Tomato breeding. We have now decided, obviously with mingled feelings, to devote our attention completely to Tomato products, leaving the enormously complex problems attendant on the breeding of other vegetables to those who by training, technique, and location are better suited to handle them. (This decision does not immediately affect our southern branches.)

We are quite content to let others take the strings out of beans, the cores out of carrots, and the curves out of cucumbers. We will devote our energies to the development of bigger and better, deeper and sweeter Tomatoes. That in itself, we think, is a man-size job. In this connection we would remind you that it is much less than 100 years ago that the despised Love Apple was looked upon as deadly poison. Today it is the Number One vegetable in the United States.

In abandoning the general line of vegetables, we wish sincerely to express our gratitude for the long years of support we have received from the gardening public. It is our deep conviction that as specialists we will make a more authentic contribution to the agricultural

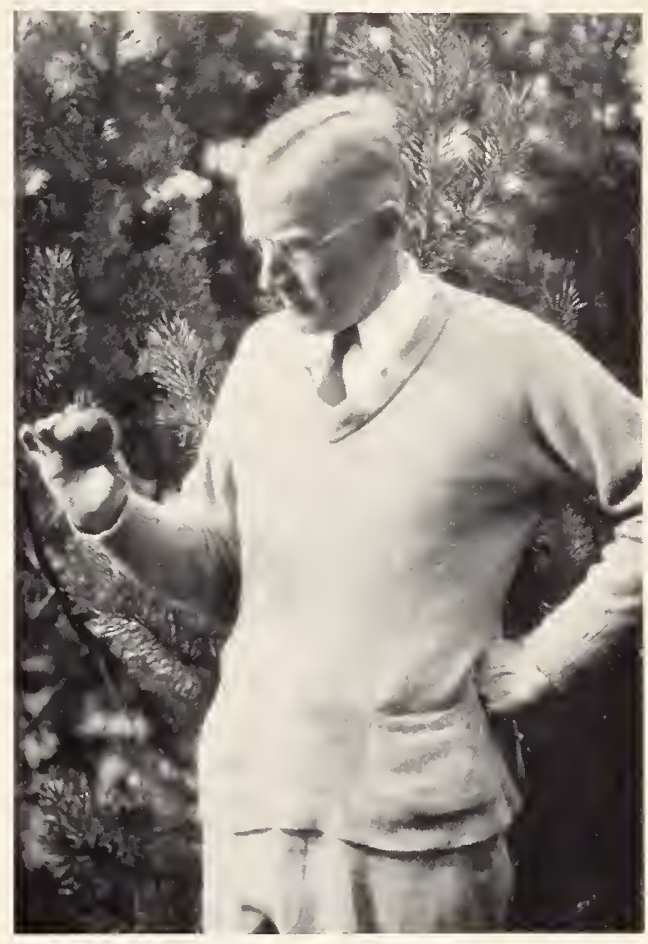

"The attainment of perfection in anything is a goal worth striving for', economy of our country than will be possible as general seedsmen.

The exactions of modern business are constantly demanding greater and greater precision. To do one thing very well is the new order, rather than to do many things quite well. It is on this premise that we humbly but resolutely make our choice, and take as our new slogan, "Stokes for Tomato."

BUSINESS FOUNDED 1881
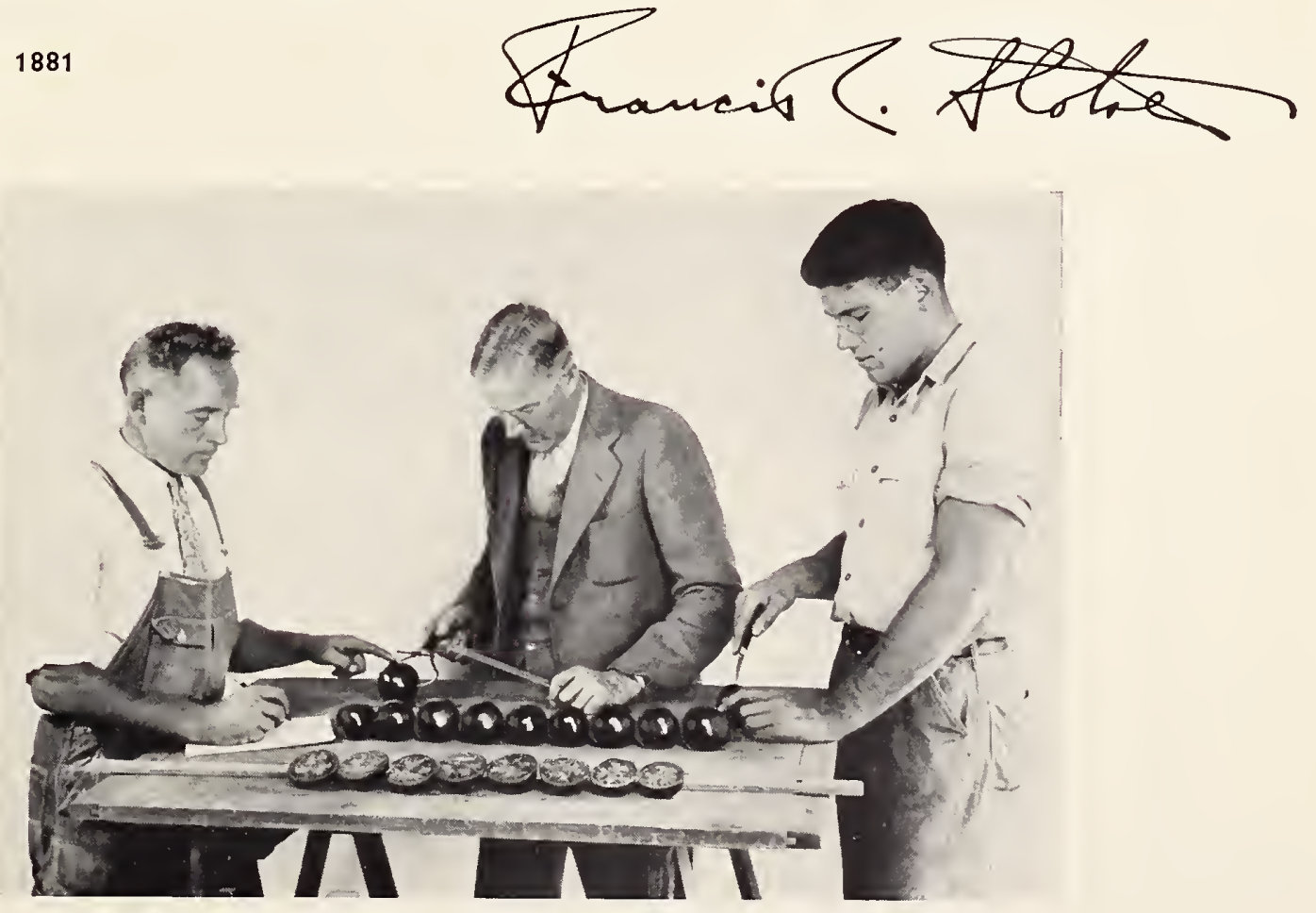

Study of interior structure and millimeter measurement with calipers is daily routine in our breeding plots 


\section{SOUTHERN PLANTS IN SOLID CARS Strong, Certified Plants Ready April 27}

In 1935 our Company sold the equivalent of 25 carloads of plants from Georgia and the Carolinas. For the most part, our customers were enormously pleased with the results. There are two sides of the business, however, which are badly in need of correction. First, we have decided completely to eliminate less-than-carload shipments. The delays and the rough handling of such shipments are such as to discourage our continuing them. For the most part, we were able to group our orders together so that our customers received their plants out of solid cars, and from all such deliveries the results were far more satisfactory.

The second point to which we are devoting our best energies is the question of collar rot. Regardless of our best vigilance and of our adhering strictly to the rules laid down by the southern officials, collar rot developed in the fields of a number of our customers. This disease is due to an organism (Macrosporium solani) which is invisible to the naked eye. It is an infection which may be carried in the wind, by mist, on the clothing of the workers, or by almost any other agency. The officials of the Department of Entomology of the State of Georgia are making a sincere and effective effort to control the disease. Our Georgia plant acreage is completely under their supervision. We are following both the spirit and the letter of their instructions and their rules, which this year include winter disinfection of the seed with bichloride of mercury, it being recently shown that this collar rot organism can be present on the surface of the seed, even though it had been previously disinfected at the time of harvest. Dr. Julian Miller has, we feel, made an important discovery in this regard and the State of Georgia is to be congratulated.

Our plants are being grown from our own seed, precisely the same stock that is offered in this Catalog. Tomato plants will be ready April 27. This offer of plants is made only to customers who can either buy in car lots or can take delivery at one of our New Jersey points, which include Moorestown, Woodbury, and Bridgeton. Precise schedules will be announced later. Solid cars, of course, can be delivered anywhere.

The plants will be strong, hardy, field-grown stock which is well rooted and well hardened. Our packing is done with great care, with ample quantities of sphagnum moss being used. The schedule of varieties and shipping dates noted below will be adhered to as strictly as the weather permits. Your inquiries and orders are respectfully solicited.

Transportation charges allowed to northern points.

VARIETIES:

Stokes Master Marglobe, and Rutgers $\left\{\begin{array}{c}\text { Approximate shipping season } \\ \text { April } 27 \text { to June } 10\end{array}\right\}$
$\$ 2.50$ per 1,000
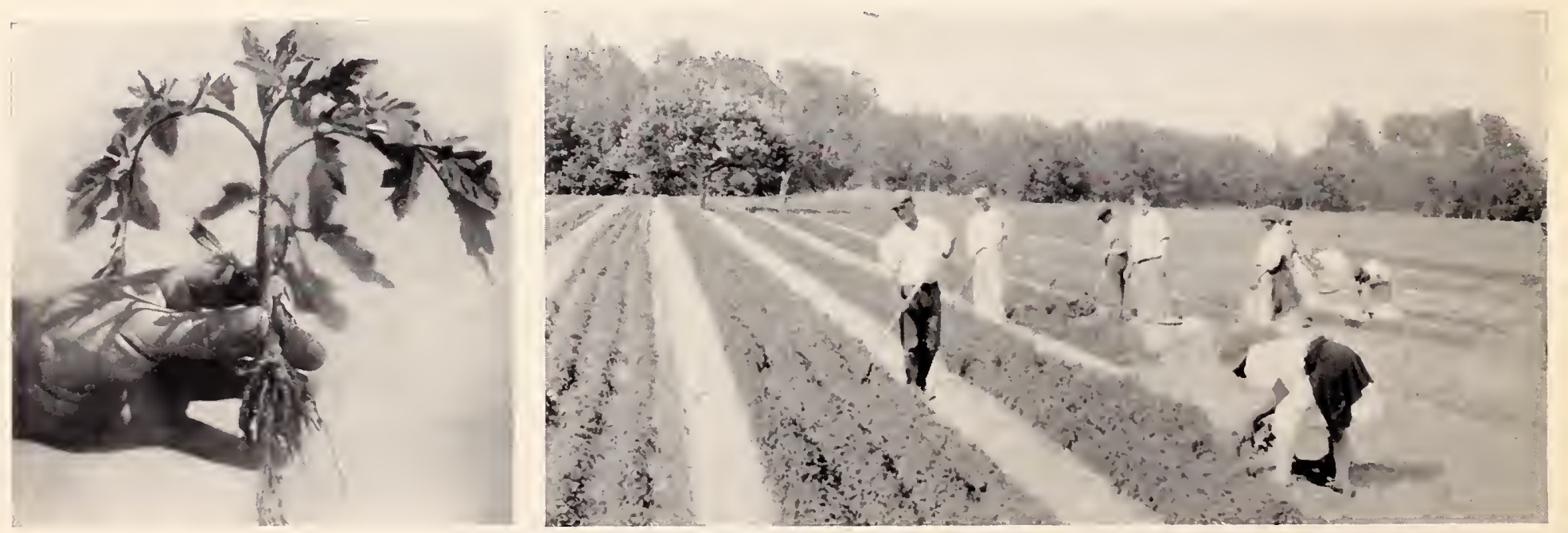

Our tomato plants are ready for shipment during the last week in April 


\section{THESE POINTS MAY HELP YOUR TOMATO PROFITS}

\section{Plant Pedigreed Stocks}

The losses consequent to carelessness in planting run-out, off-type, low-producing strains are difficult to compute. Such stocks are partly responsible for the 3-ton yields that are so prevalent. The growers who are making the profits in Tomatoes are planting nothing but strains that are bred for their special purpose-stocks that have been disinfected for seedborne diseases and have recently been tested for strong germination and high vitality.

\section{Southern Plants Are a Success}

All indications show that they are here to stay, for the reason that a stronger plant can be bought for less money. This, of course, does not apply to the men who use blocked plants. Both growers and state officials are putting up a winning fight against diseases. Our one note of warning is that you make certain that the plants you receive from the South have been grown from seed that has a pedigree. This last year's records again prove that most of the heaviest acreages in the North were produced from Southern-grown plants.

\section{Handle Your Plants Carefully}

If you are using Southern plants, and if you trench them before planting, thoroughly wet down the trench, place the plants in it, fill the trench, and then wet it down again. Under no circumstances should you have flowing water in the trench itself, for if there are disease organisms on any of your plants you are likely to spread them down the whole row. Plants of the Marglobe type are usually spaced 4 feet apart in the row, in rows 5 feet apart. In the latitude of Philadelphia we recommend that the plants be set in the field as near May 1 as possible.

\section{Have Your Soil Analyzed}

Calcium and magnesium are very essential to the growth of Tomatoes, but if there is plenty of organic matter in the soil, deficiency of these is not so serious. The use of finely ground dolomitic limestone, 300-screen, is strongly recommended. We are of the opinion that any great deficiency of these elements may have a direct connection with heavy infestations of collar rot and other diseases.

\section{Use Plenty of Fertilizer}

Many of our customers are succeeding with Tomatoes with an application of stable manure, some with an application of chemical fertilizer. A combination of both is recommended when available. Your County Agent can make recommendations on this after the soil analysis. A good standard formula is $5-10-8,800$ pounds in the row and 200 pounds as a sidedressing after the plants have been in the field about a month.

\section{Cultivate Constantly}

For this we recommend two-horse riding cultivators with 1 -inch teeth next to the plant and 2-inch teeth in the centers. The field will bear cultivating once a week. Cross the rows with a one-horse cultivator. Crab grass and weeds must be kept down. As one good grower has said, "One crop at a time is enough for any field."

\section{Keep Ahead of Potato Bugs and Tomato Worms}

The important matter of spraying must not be neglected. A combination of calcium arsenate and Bordeaux Mixture is very desirable. Use plenty of pressure on your pump-at least 200 pounds. Good, ready-mixed formulas are now commercially available at a reasonable cost.

\section{Watch Your Picking}

This is a vitally important factor in Tomato profits. It will undoubtedly profit you to pay your pickers by the day and not by the basket. If you do not believe this, give it a trial. We have some very illuminating figures on the subject. One grower reports an average cost of 3.7 cents per basket. But the real gain is shown on the inspection platform. It will pay any grower to be with his men in the field as much as possible. The man who won the prize for first quality in New Jersey in 1935 invariably stored his Tomatoes under a tarpaulin for a 12-hour period before delivering them to the cannery. His season's averages were as follows: U. S. No. 1, 86 per cent; U. S. No. 2, 13 per cent; Culls, 1 per cent. His net profit per acre was in excess of $\$ 135$. He used Stokes Master Marglobe, Southern-grown plants.

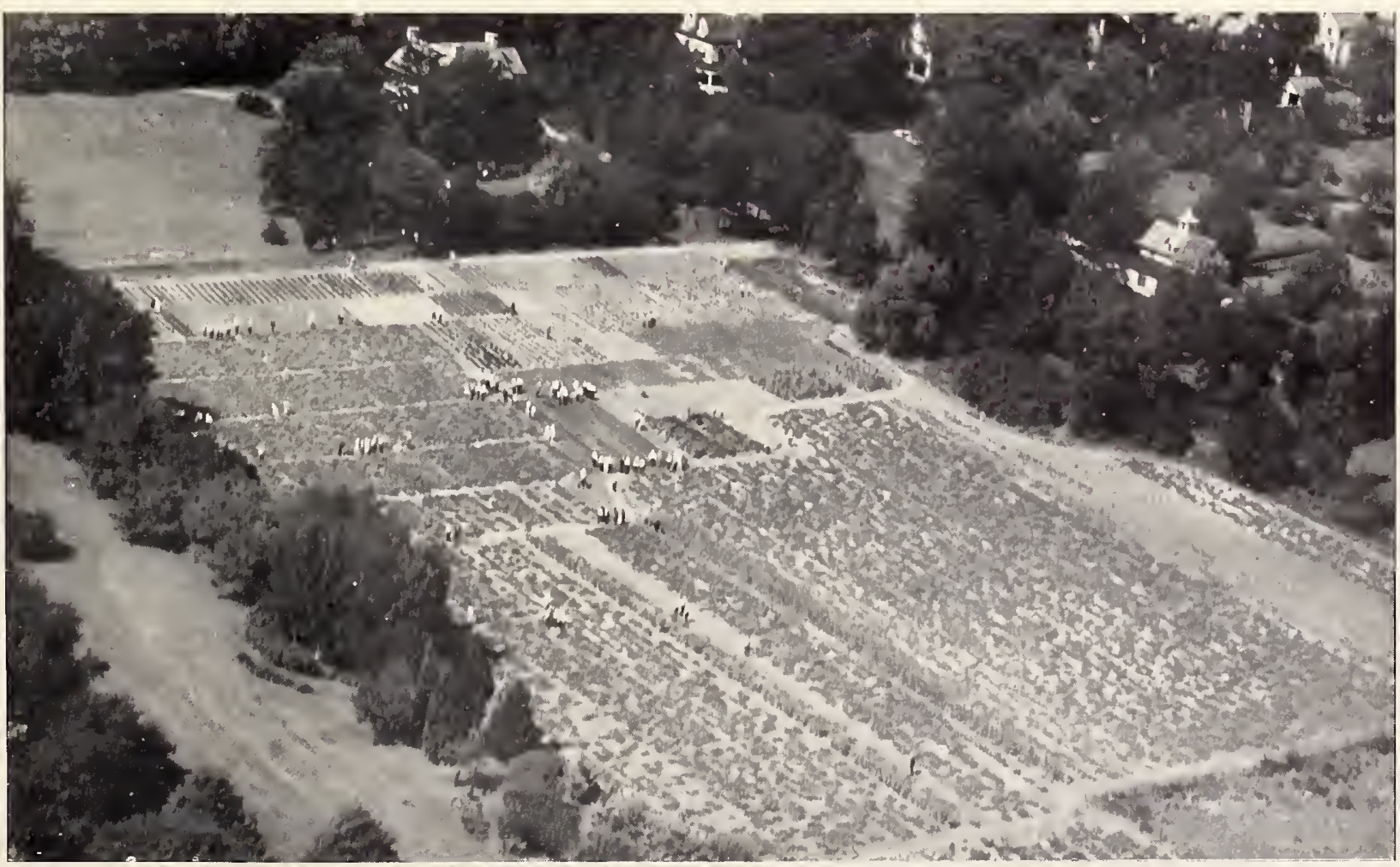

Stokesdale Proving Grounds on occasion of a midsummer field meeting 


\section{STOKESDALE (1936 INTRODUCTION) APPROACHES EARLIANA IN SEASON,-MARGLOBE IN QUALITY}

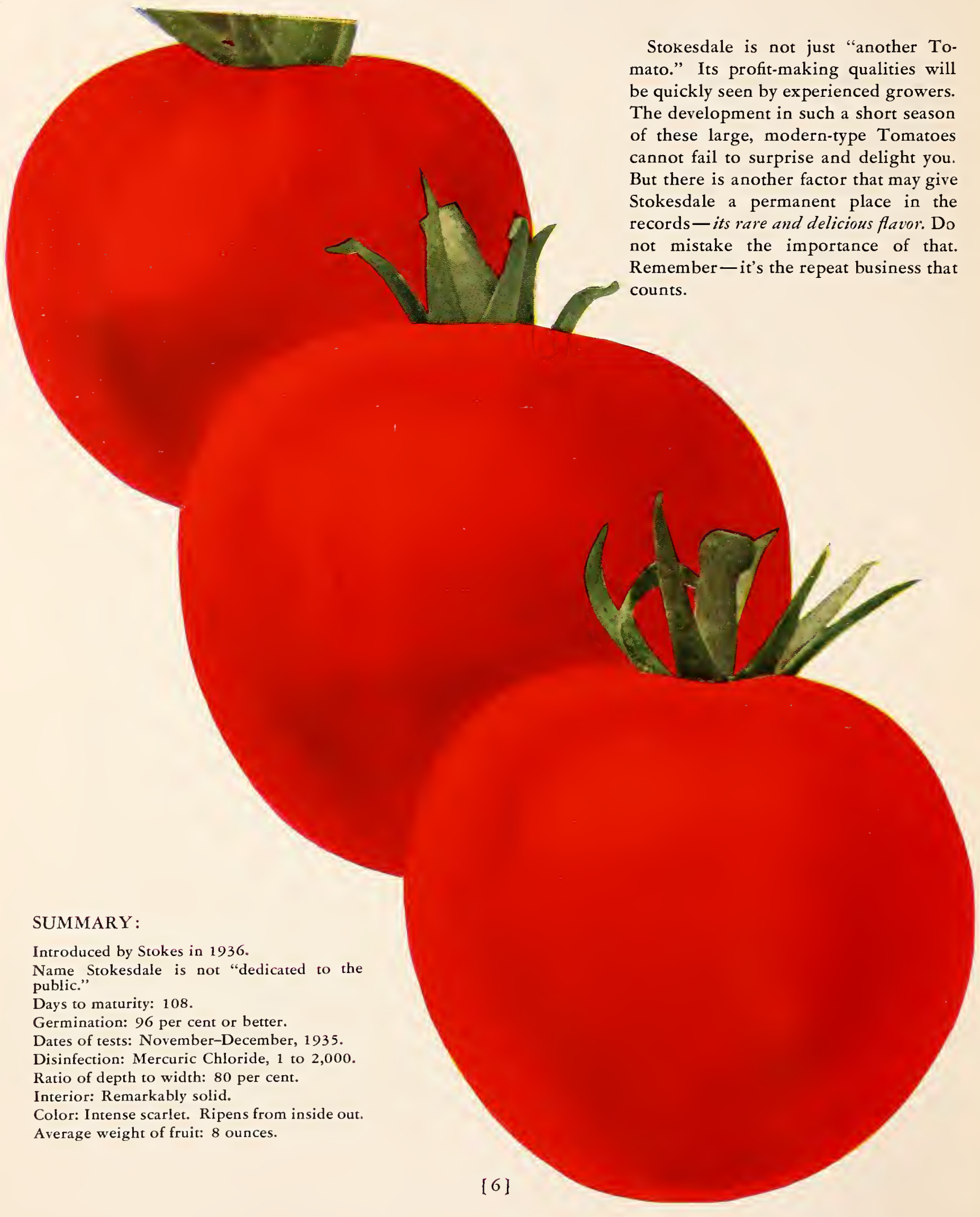




\section{WE PREDICT A BRILLIANT FUTURE FOR THE STOKESDALE TOMATO}

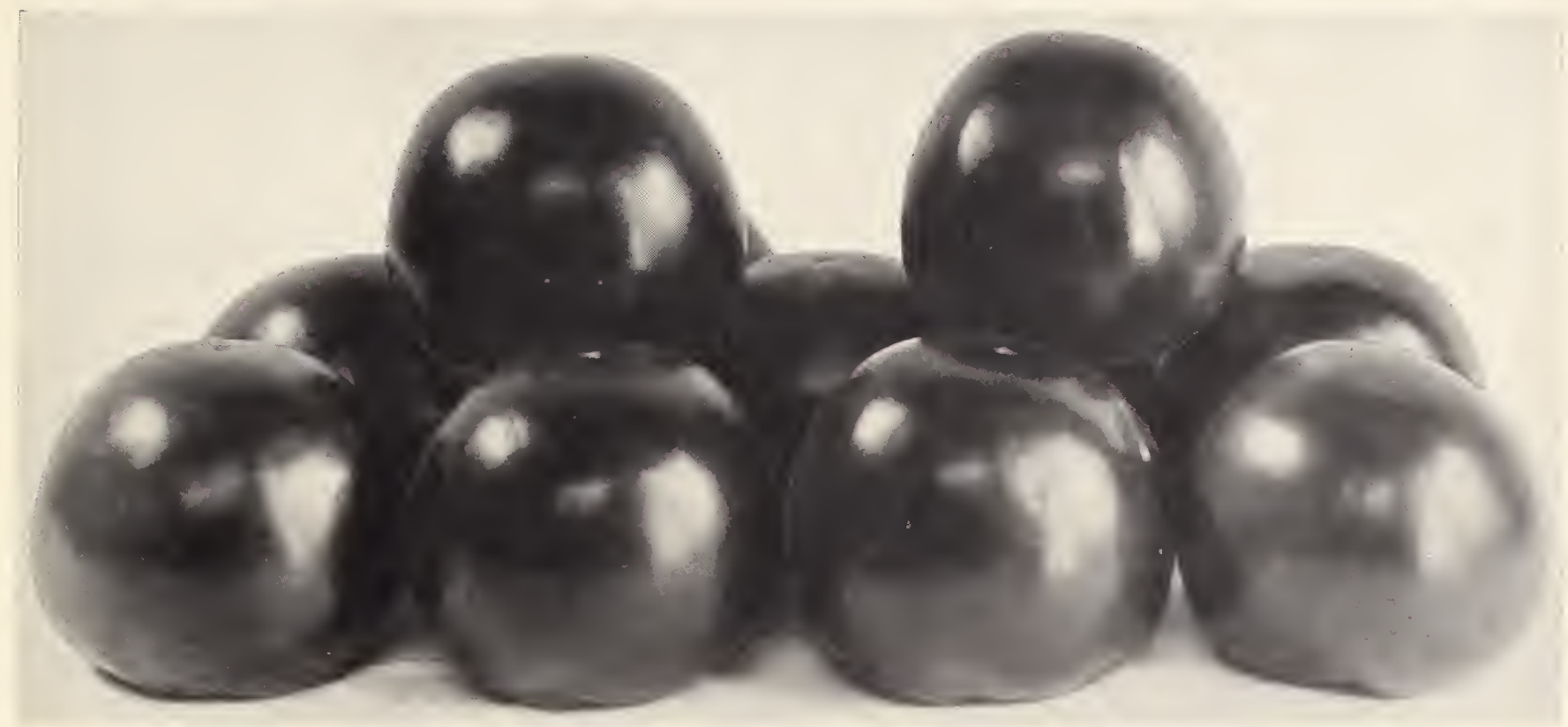

Earliness, size, depth, interior color, and freedom from stem-crook are favorable features of Stokesdale

We have named this Tomato for our Stokesdale Proving Grounds, where it originated. We are giving it the place of honor in this Catalog because we feel that it deserves it. Admitting that one or two more years' work will be required further to perfect and fix its type, we already look on it as a distinguished Tomato. It is an extra-early type, maturing some two weeks in advance of Stokes Master Marglobe, at the same time having many of the important fruit characteristics of that variety. There is one outstanding point of difference-Stokesdale ripens from the inside out. It must be remembered that Stokesdale is now only in its fourth generation, whereas Stokes Master Marglobe is in its twelfth. For that reason the same perfection of type must not yet be expected in the two stocks.

Stokesdale is enthusiastically recommended to growers who either can profit by a quick-maturing Tomato or who, because of high latitude or altitude, must have a Tomato that will ripen in a short season. This factor is particularly important in the northern tier states and in Canada, where full crops of Stokes Master Marglobe have not been possible.

Stokesdale originated in our seed-breeding grounds at Moorestown in 1933. It was found in a single plantselection of Bonny Best. Whether it was a mutation from that variety or whether it was an accidental cross between Bonny Best and Marglobe, we do not know. The fact remains that a new Tomato was found under these conditions, and its rare qualities of earliness, size, flavor, interior solidity, and interior color were promptly recognized. Since that time we have been making single plant-selections from it at Stokesdale, at the old Floracroft Greenhouses, and at the trial-grounds of our company establishment at Weslaco, Texas. We now have a very limited amount of seed to offer. The supply this year will not be adequate for the demand, but we want it to be spread as far as possible in order to give it complete tryouts in all parts of the country.

If you are one of those growers who can profit by quick maturity, do not fail to give Stokesdale space in your operation. You will be vastly impressed with the fact that here is a Tomato of the extra-early classification with the inherent qualities of a modern, main-season variety. The trade has been looking for that combination for a long time. It is foolish to predict the future of any new variety, but our feeling about Stokesdale is that it will take a place of prominence. It is possible that it may replace such Tomatoes as Earliana, Bonny Best, John Baer, and even Pritchard. However, like all other new things, it must be given a country-wide trial before its place is fixed. We urge that you give Stokesdale a full test. It is possible that it will rebuild your entire Tomato schedule.

Price, Postpaid: Trade pkt. $\$ 1 ; 1 / 4$ oz. $\$ 1.75 ; 1 / 2$ oz. $\$ 3 ;$ oz. $\$ 5 ; 1 / 4$ lb. $\$ 17.50$ 


\section{STOKES MASTER MARGLOBE*}

\section{THE IDEAL SHIPPING TYPE,-DEPTH, WEIGHT, BRILLIANCE}

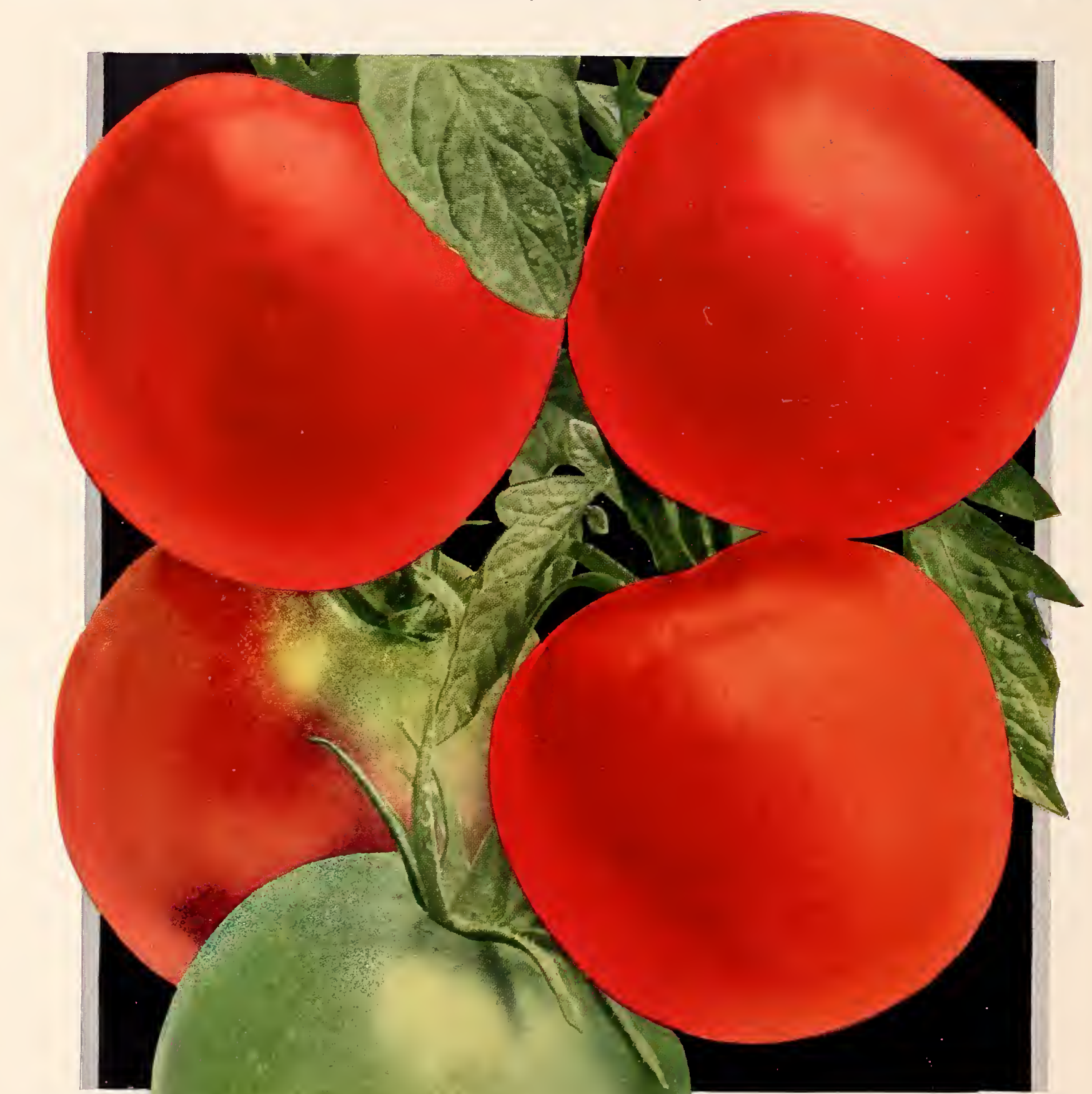

SUMMARY :

Introduced by Stokes in 1930.

Trade-Mark Registered. Use of name prohibited to unlicensed firms.

Days to maturity: 118 .

Certified 1935 by New Jersey Department

Bred for High

Production and

High Perfection of Agriculture.

Germination: 95 per cent or better.

Dates of tests: November-December, 1935.

Disinfection: Mercuric Chloride, 1 to 2,000 .

Ratio of depth to width: 95 per cent.

Interior: Completely coreless, heavy in solids.

Color: Brilliant scarlet when ripe.

Average weight of fruit: 6 ounces. 


\section{STOKES MASTER MARGLOBE*}

\section{EXCELLENT FOR MANUFACTURE,-FLAVOR, SOLIDS, PRODUCTION}

Stokes Master Marglobe is now generally conceded to be one of the great varieties. We have devoted eight years to its development. Its present wide acceptance comes as a result of the most detailed planning, supported by thoroughness and care in developing these plans. It has required 369 acres (all state certified) for the production of our 1936 seed-supply, but already, two months before the main planting season opens, we are 80 per cent sold. Almost any good thing is imitated by those who are unwilling to lay their own groundwork. Planters desiring the genuine Stokes Master Marglobe are urged to make certain that they are securing the original stock. For your protection, and for the protection of our own heavy investment-running well into five figures-the name Stokes Master Marglobe is now guarded by a Registered Trade-Mark.

Stokes Master Marglobe has been bred both as a shipping and a manufacturing Tomato. Both require heavy production, and that has been our first consideration. No Tomato can now attain full success on the large northern markets unless it has depth and interior solidity. The

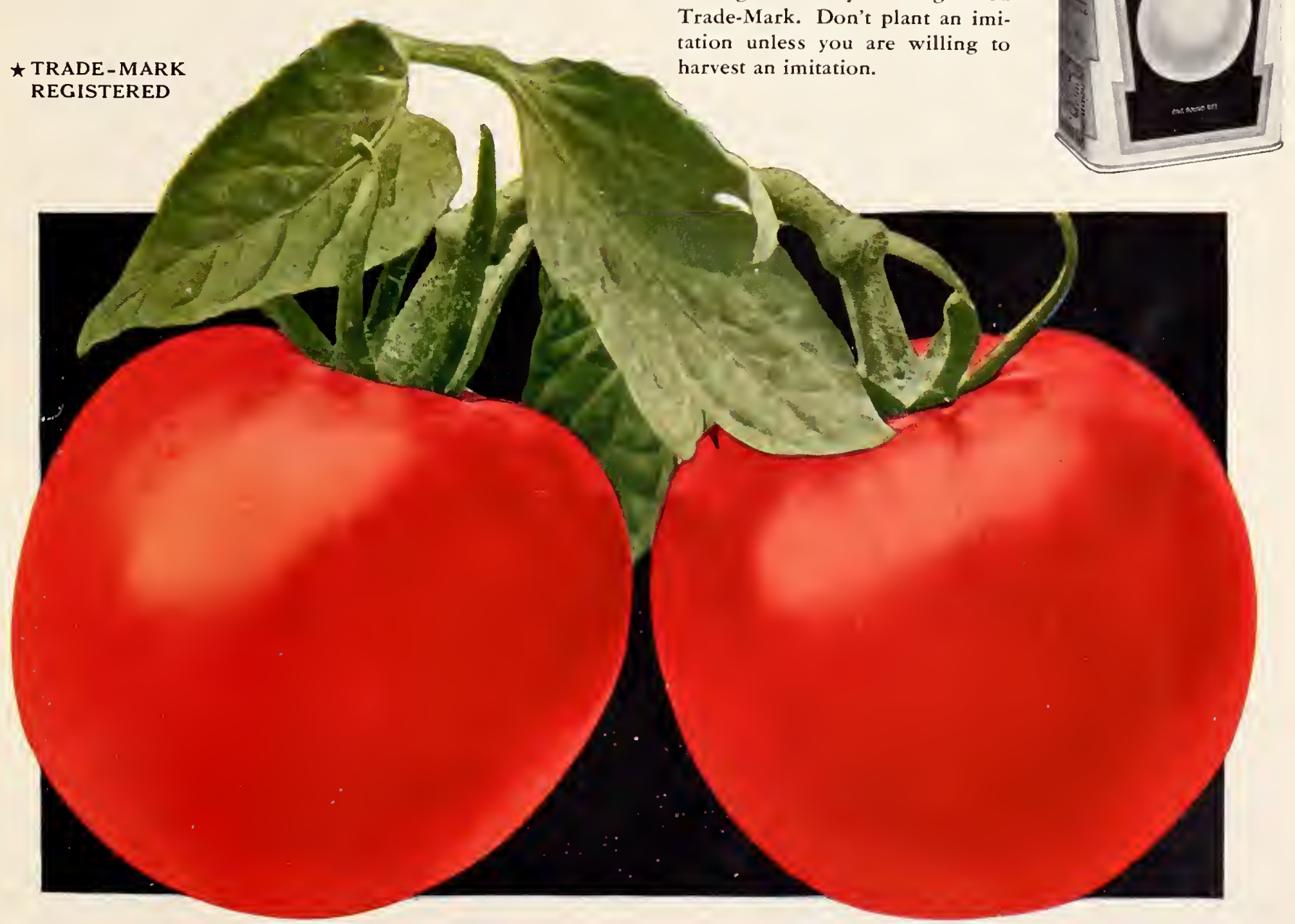

consumer rightly demands that extra slice, and the tradesman rightly demands keeping quality.

The manufacturer of Tomatoes must have a raw product high in solids, low in mold count, and pleasing in flavor. These are assured in Stokes Master Marglobe by its interior structure, its freedom from blossom-end scar, and a richness of taste that has seldom been equaled. Its color is dependent on its degree of ripeness, and ripeness is dependent on vigilance with the picking crew, supplemented by a 12-hour storage under a tarpaulin before factory delivery. Price, Postpaid: Trade pkt. 25 cts.; oz. 50 cts.; $1 / 4 \mathrm{lb}$. $\$ 1.50$; lb. $\$ 5$.

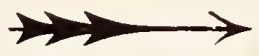

In addition to securing a Registered Trade-Mark for the name Stokes Master Marglobe, we have further protected the variety by packing it under a label which is also guarded by a Registered Trade-Mark. Don't plant an imitation unless you are willing to harvest an imitation.

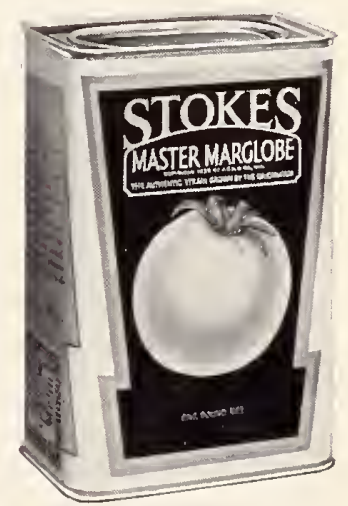

\section{THIS PACKAGE IS YOUR PROTECTION}




\section{GREENHOUSE FORCING STRAIN No. 6-87 A SELECTION OUT OF STOKES MASTER MARGLOBE}

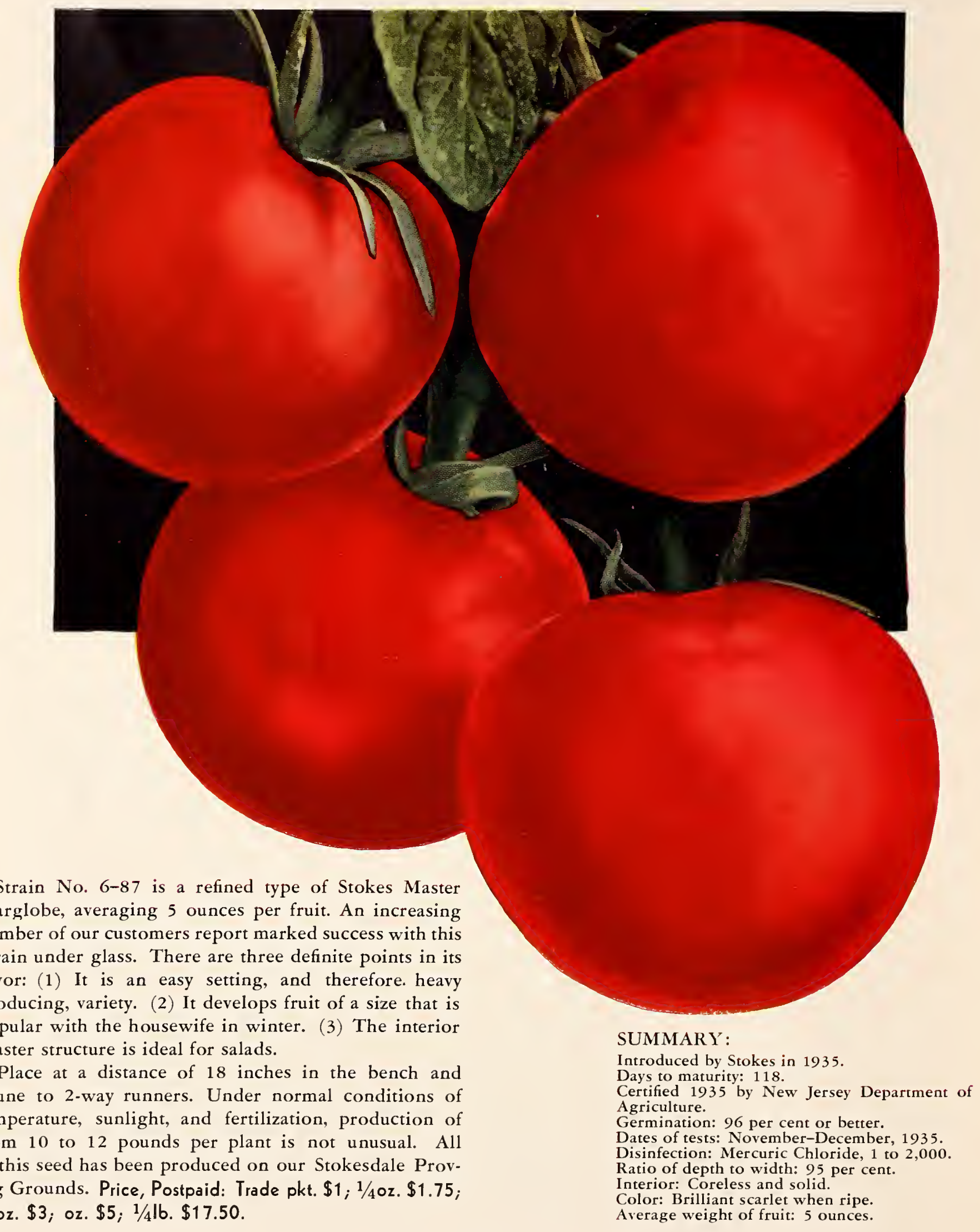




\section{LANGE'S EARLIANA \\ ITS WIDE ACCEPTANCE IS DUE TO HEAVY CROWN-SET}

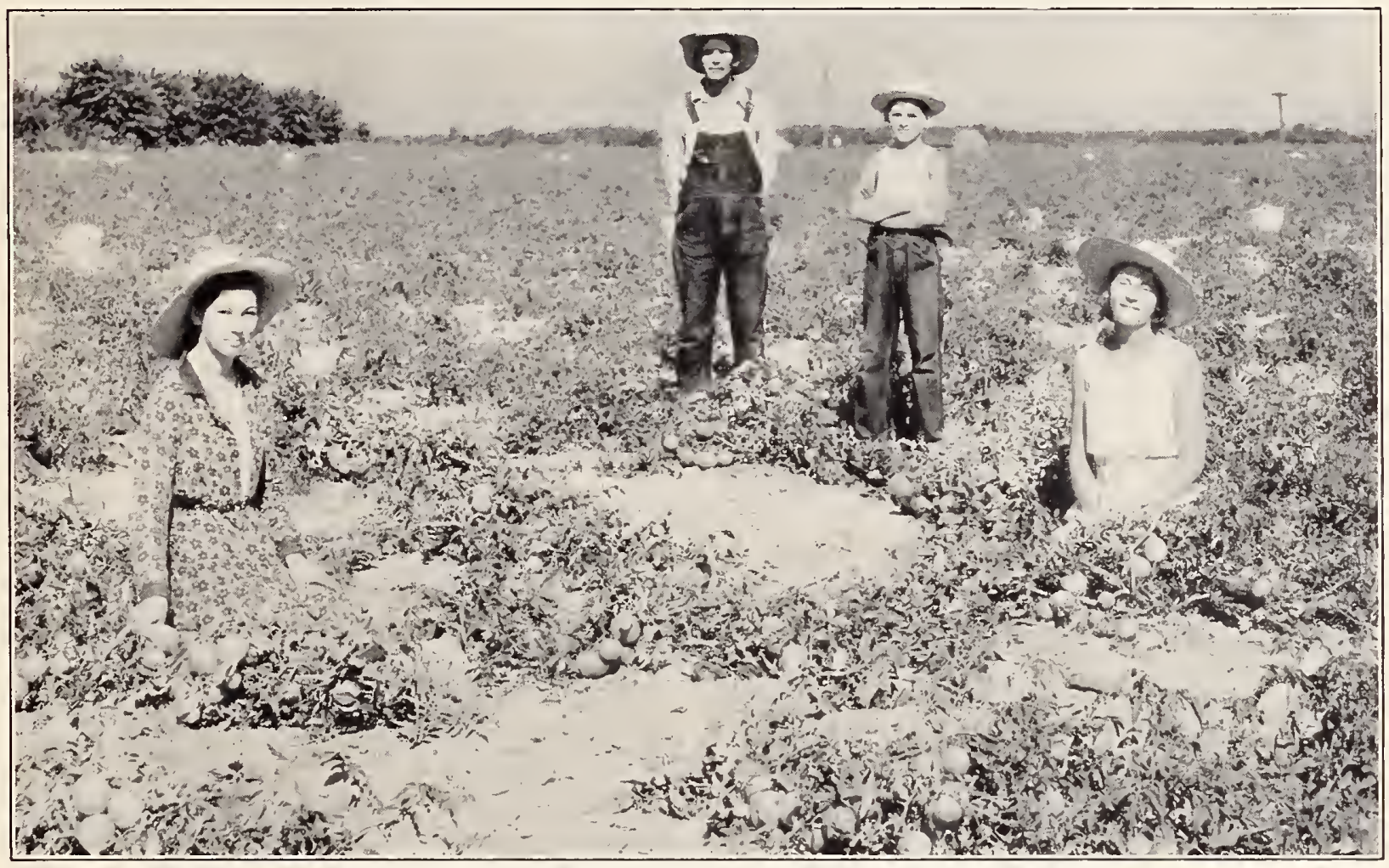

This photograph speaks for itself. We have only to say that it portrays part of the Lange family out in their Earliana field on their farm near Swedesboro, N. J.

Sparks' Earliana was introduced by Johnson \& Stokes, our honored forebears, in 1900. For over 30 years this variety has held a respected position as the leader of the extra-early class. Some five years ago our Gloucester County neighbor, Mr. Ernest Lange, found a plant in his Earliana field which had developed an unusually heavy crown setting. Mr. Lange saved this seed, and, after making further selections, sold the introductory rights to our Company.

The unusual success of the variety is obviously due to the fact that fully half of the crop is available during the first 10 days of harvest. The above photograph tells the story better than we can. This crop was set out in Gloucester County, New Jersey, the first week in May. The first ripe Tomato was gathered on June 17. The first five baskets were gathered on June 22 , and thereafter 50 to 100 baskets were gathered daily. It is not at all uncommon for the crown-set to carry 6 to 12 fully developed fruits. The specimen photograph in color is typical of the type. Lange's Earliana is still an Earliana. It nevertheless is a fine representative of its class.

Price, Postpaid: Trade pkt. 25 cts.; $1 / 20 z .60$ cts. oz. $\$ 1 ; 1 / 4$ lb. $\$ 3.50 ;$ Ib. $\$ 12$

\section{SUMMARY:}

Introduced by Stokes in 1933. Days to maturity: 110 . Germination: 95 per cent or better.

Dates of tests: November-December, 1935.

Disinfection: Mercuric Chloride, 1 to 2,000.

Ratio of depth to width: 75 per cent. Interior: Open. Color: Light scarlet when ripe.

Average weight of fruit: 5 ounces.

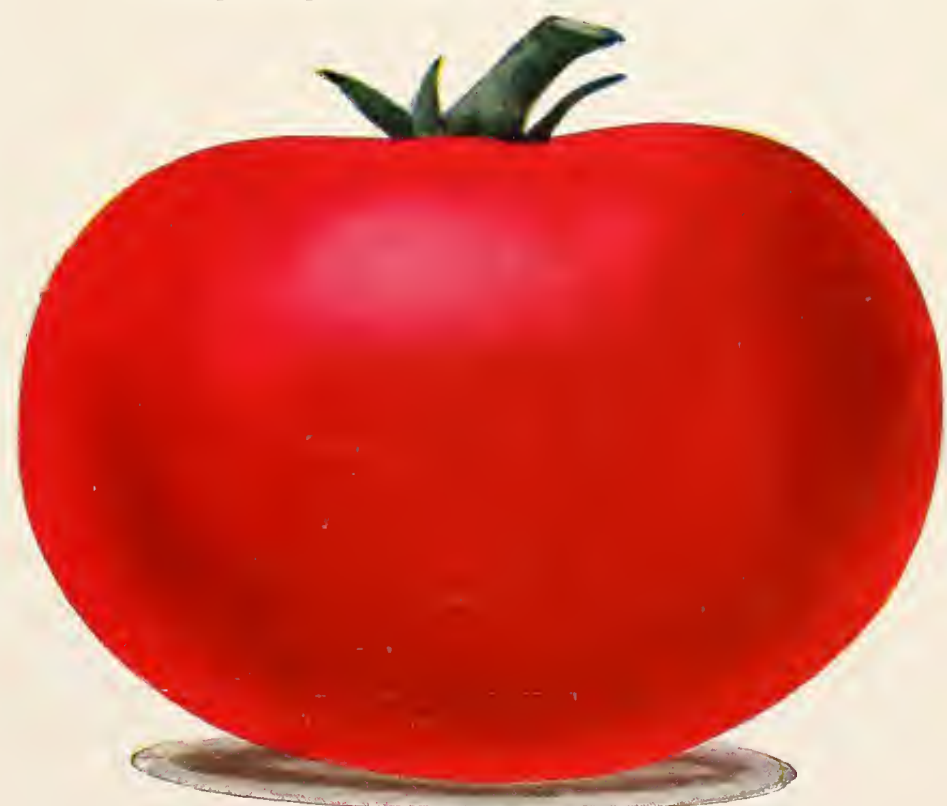




\section{THE RUTGERS TOMATO A PROMISING SORT FOR CANNERIES ON ACCOUNT OF COLOR AND HIGH YIELD}

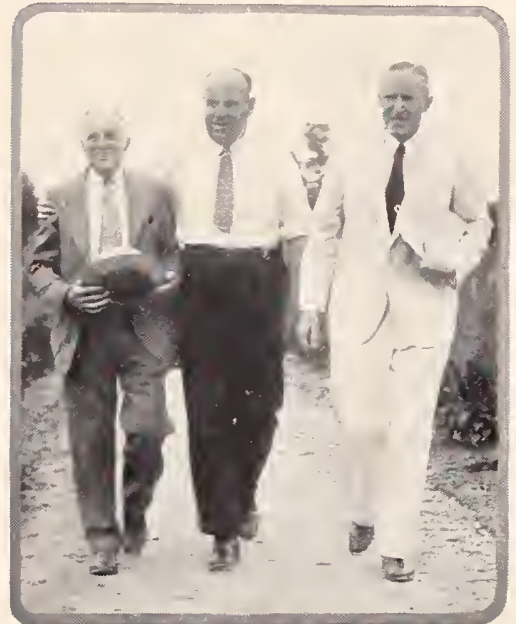

Messrs. Hall, Schermerhorn, and Stokes at our Company proving grounds

SUMMARY :

Introduced by New Jersey Experiment Station, 1935.

Days to maturity: 118.

Certified' 35 by N.J. Dept. of Agric. Germination: 92 per cent or better.

Date of test: December, 1935.

Ratio of depth to width: 75 per cent. Interior: Solid.

Color: Intense scarlet. Ripens from inside out.

Average weight of fruit: 8 ounces.
This Tomato in its present form is of doubtful market value, and is not recommended for shippers. Too large a proportion of the fruit is heavy and flat and will not pack well in the lug box. The Rutgers has been developed as a cannery Tomato and as such it may establish a place of importance. Its most striking feature is its brilliant interior color, a factor which counts 30 per cent in the Government grading of Tomato juice. However, the Government counts flavor at 40 per cent, and so far we are not much impressed by the flavor of Rutgers. The rough types may eventually be eliminated by further selection. We, of course, can only report on the stock as we find it. Rutgers was given a thorough test under varying conditions this past season. About 50 per cent of the tests brought favorable reports.

The Rutgers Tomato is the product of a cross between Marglobe and J. T. D., made some years ago on the Campbell Soup Co. Farms. It was later turned over to Prof. L. G. Schermerhorn of the New Jersey Experiment Station, and, after approximately six generations' selection, was formally introduced under the name of Rutgers. Its habit of ripening from the inside out should prove valuable to the manufacturer of Tomato products, provided the grower can revise his ideas of picking. Under proper balance of soil and fertilization, this Tomato should develop good acre yields. Its future place of importance will depend largely on the stock-seed control. The seed we offer herewith is the product of stock that has been produced from Prof. Schermerhorn's stock seed. Up to this time we have not done any of our own breeding work on Rutgers.

Price, Postpaid: Trade pkt. 25 cts.; oz. 50 cts.; 1/4lb. $\$ 1.50$; lb. $\$ 5$

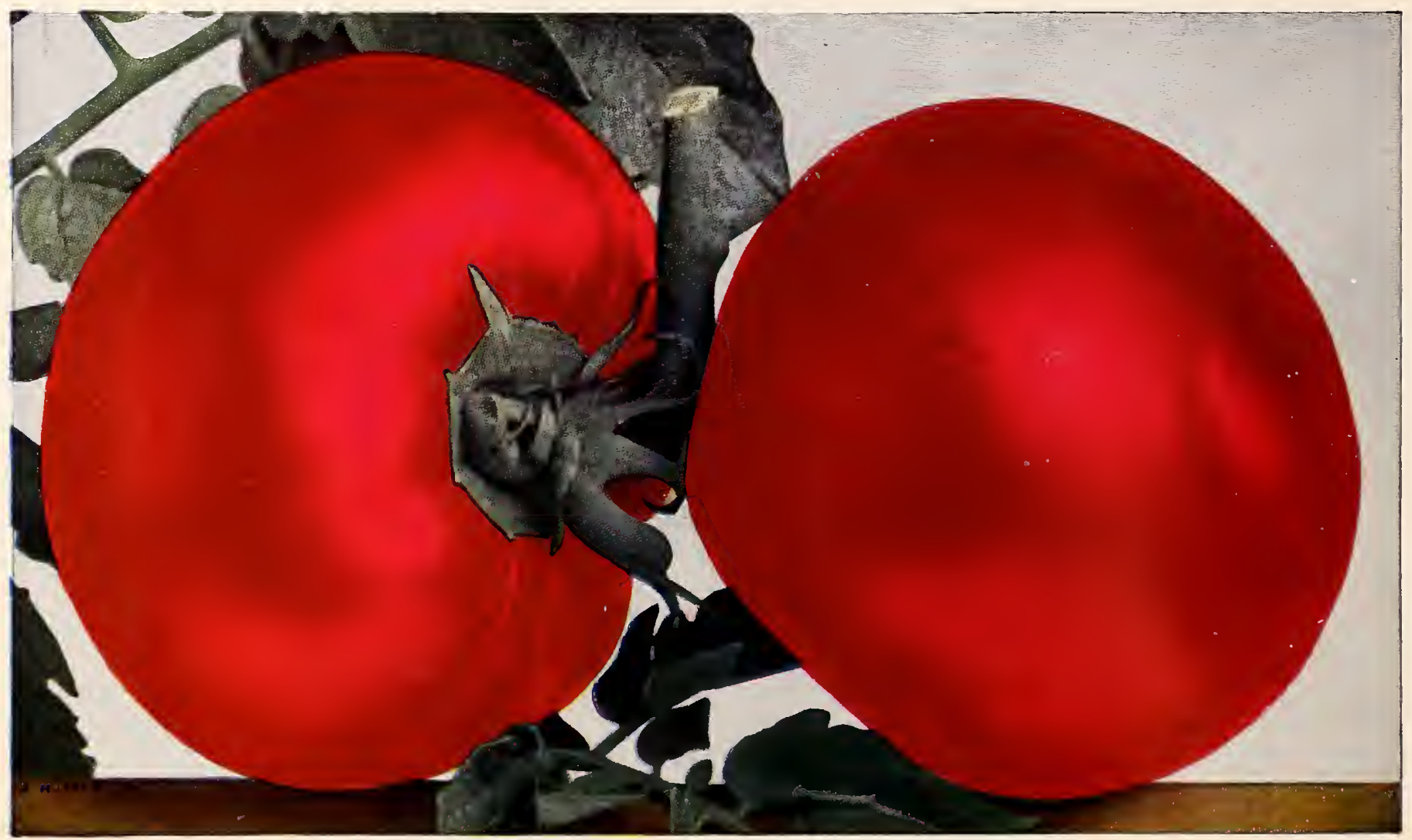




\section{SUPER-STANDARD BONNY BEST}

A GRAND STRAIN OF THE

$B O N N$ Y B E S T

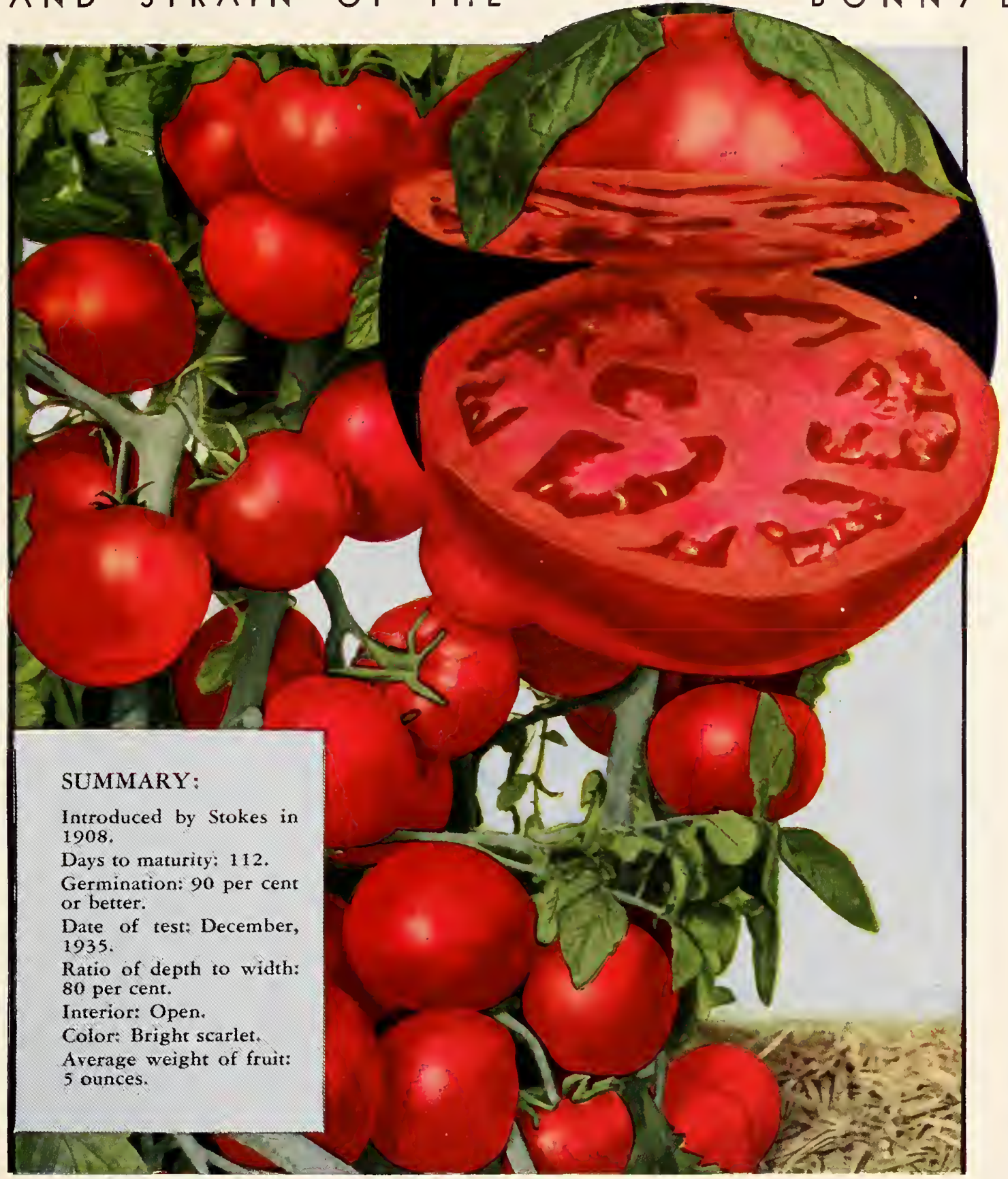

For over 10 years Super-Standard Bonny Best has shown an excellent profit for a large number of our customers. This holds for either hothouse production or intensive field cultivation. It is particularly valuable in the northern tier states, where Stokes Master Marglobe cannot reach full maturity. It is now 27 years since Walter P. Stokes first offered the original Bonny Best. Obviously in that time many robust Tomatoes have been introduced. The modern type is a vast improvement over its predecessor of three decades ago, but even with all these improvements the Bonny Best still holds an important place in the Tomato economy in this country. Our Super-Standard strain will produce strong, vigorous vines, with fruit that is unusually large and solid for this variety. The flavor of the fruit is delicious. In Wisconsin, Michigan, Ontario, New York, and New England, Super-Standard Bonny Best will give very great satisfaction either for market or for manufacture. As one of our own introductions, we can still recommend it with assurance. This Super-Standard strain will prove to be a worthy one. Price, Postpaid: Trade pkt. 25 cts.; $1 / 20 z .60$ cts.; oz. $\$ 1 ; 1 / 4$ lb. $\$ 3.50 ;$ lb. $\$ 12$. 


\section{PRITCHARD}

THE LAST ORIGINATION OF A GREAT PLANT BREEDER

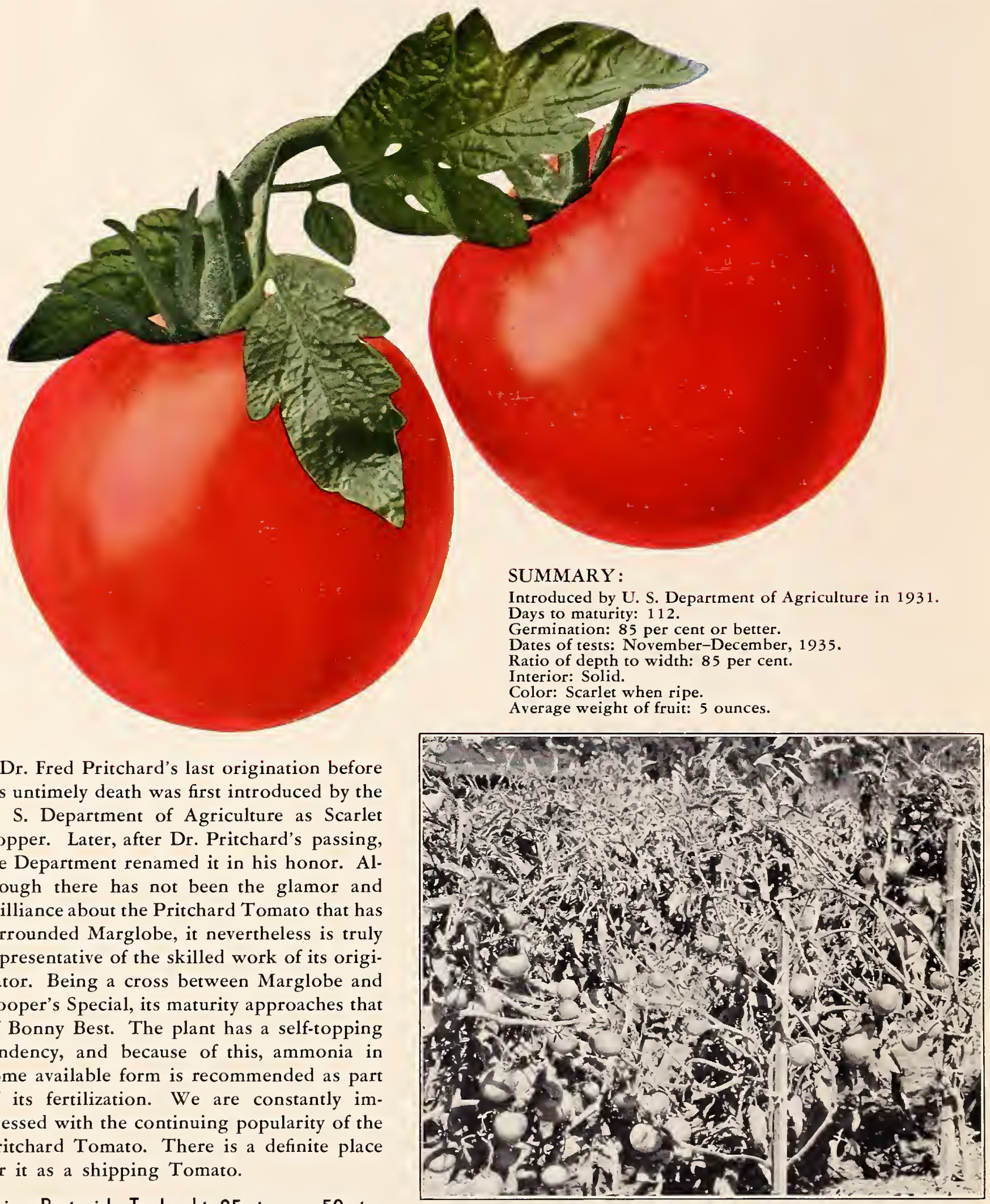

Price, Postpaid: Trade pkt. 25 cts.; oz. 50 cts. $1 / 4$ lb. $\$ 1.50 ;$ lb. $\$ 5$

The great productiveness of Pritchard is shown in this photograph, taken in the garden of Mr. R. N. Neeley, of Sanford, Fla. 


\section{B A LTIMORE}

NEW JERSEY CERTIFIED PRODUCED FROM INDIANA BALTIMORE

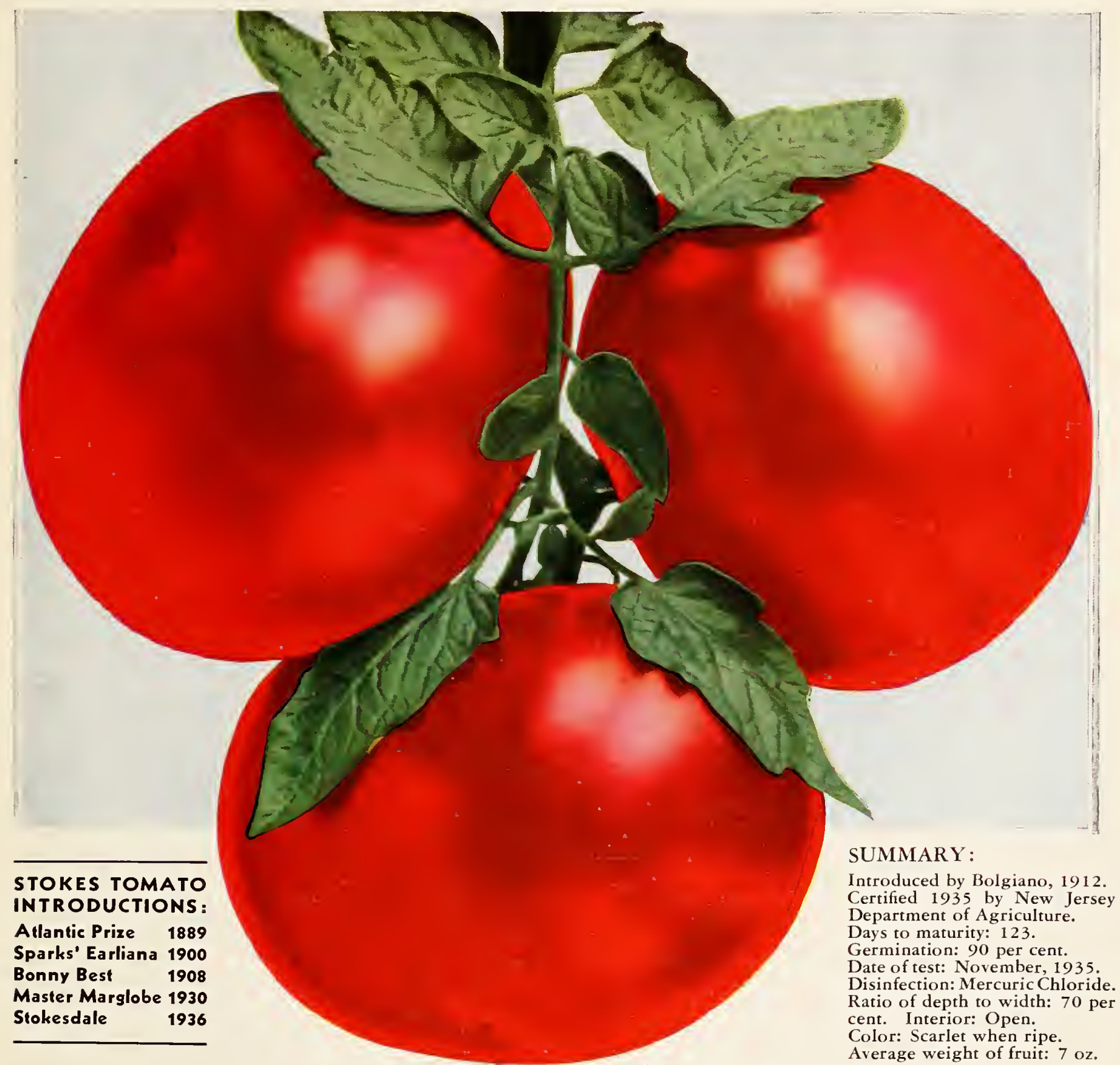

The Baltimore Tomato seems to thrive best in the limestone soils of Indiana. On account of its susceptibility to fusarium wilt, this variety is no longer an important factor in eastern production. Livingston introduced the Stone Tomato in 1889, and in $1912 \mathrm{~J}$. Bolgiano introduced the Greater Baltimore, an earlier and deeper type of Stone. The stock we offer is grown from the Indiana-Baltimore strain. It is of our own production and carries the New Jersey state certification.

Baltimore is not recommended as a shipping Tomato. Its shape is against it. The tradesman will no longer pay the full price for a flat Tomato. The slices just aren't there. Manufacturers of Tomato products have liked Baltimore because of its color. On the other hand, we are not impressed with its flavor. The vine-growth is medium heavy. The season is late. Provision must be made on the belt for elimination of the blossom-end scar.

Price, Postpaid: Trade pkt. 25 cts.; oz. 40 cts.; 1/4lb. $\$ 1.25$; lb. $\$ 4$ 


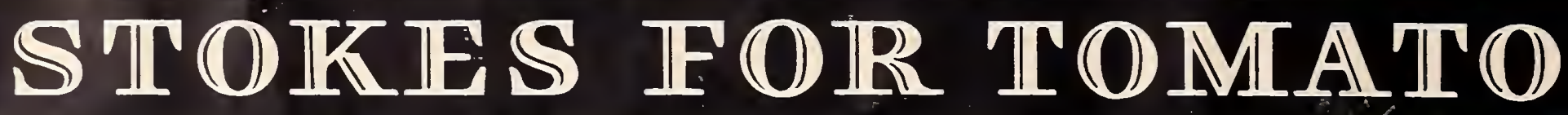

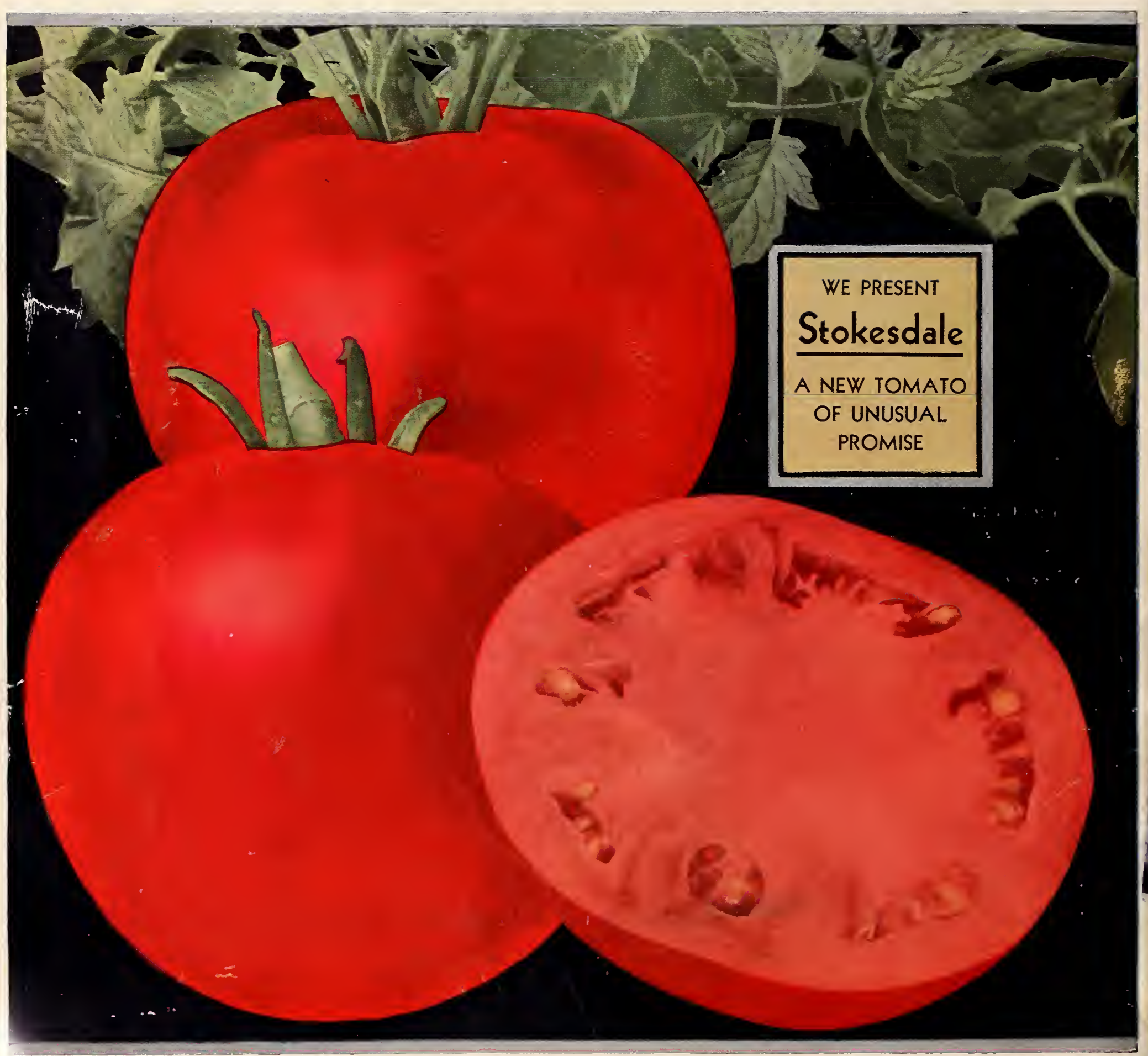

